RPP-43636, Rev. 0

\title{
Valve Funnel Spring Pin Press Performance and Functional Requirements Evaluation for Special Tools and Equipment
}

\author{
JT Witherspoon \\ Washington River Protection Solutions \\ Richland, WA 99352 \\ U.S. Department of Energy Contract DE-AC27-08RV14800 \\ EDT/ECN: DRF UC: \\ Cost Center: Charge Code: \\ B\&R Code: Total Pages: 13
}

Key Words: Valve Funnel Spring Pin Press, Performance and Functional Requirements, Evaluation

Abstract: This evaluation allows use of the valve funnel spring pin press and describes appropriate handling instructions for the tool. The engineering evaluation is required for operations and field use of special tools and equipment.

TRADEMARK DISCLAIMER. Reference herein to any specific commercial product, process, or service by trade name, trademark, manufacturer, or otherwise, does not necessarily constitute or imply its endorsement, recommendation, or favoring by the United States Government or any agency thereof or its contractors or subcontractors.
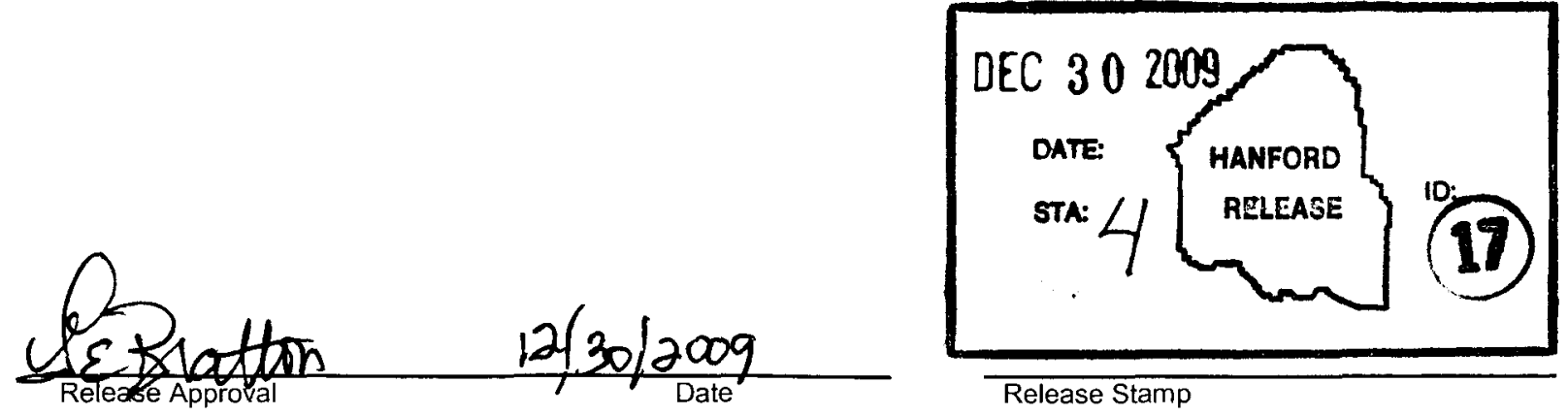

Release Stamp

Approved For Public Release 


\section{PERFORMANCE AND FUNCTIONAL REQUIREMENTSIEVALUATION FOR SPECIAL TOOLS AND EQUIPMENT}

RPP No. 43636 Rev. 0

Page 1 of 3

\begin{tabular}{|l|l|}
\hline $\begin{array}{l}\text { Evaluation of Suitability for Intended Use } \\
\text { (TFC-OPS-MAINT-C-01) }\end{array}$ & $\square$ New Procurement (TFC-ENG-DESIGN-C-34) \\
\hline Work Package No.: & Purpose of Procurement: \\
\hline
\end{tabular}

\section{SECTION 1 REQUEST}

1.1 Brief Description (identify items - include form, fit and function as appropriate):

Several valve funnels are being removed for modification or replacement in valve pits AP-02A, AP-02D, AWA, AZ, and pump pit $\mathrm{AZ}-01 \mathrm{~A}$ as described in ECN-726508 R0. These funnels are secured by spring pins (roll pins) that have been difficult to remove in the past. This device clamps on to the valve funnel and utilizes a threaded shaft to press the spring pin out of the valve funnel as it is turned. A strap has been added to the inside diameter of the clamp to aid in tool-to-funnel alignment, as pictured on pages 6 and 7 of the attached photos. Several 3/16" and 1/4" diameter pins, included with the tool, are driven by the large 9/16" screw and press the spring pin from the funnel. The included pins are different lengths to accomidate varying positions and lengths of spring pins found in the valve funnels. Utilization of this tool will minimize side loading of the valve stem and prevent potential damage from spring pin removal.
1.2. Was an Engineering evaluation previously performed and documented?
Yes $\bigotimes$ No $\square$ Unknown

If YES, Document Number and Revision:

Is the existing evaluation adequate? $\square$ Yes $\square$ No $\square$ N/A (explain below if necessary)

1.3 Requestor/Phone No./Date (optional)

K A Baird

$1376-5939$

/

\section{SECTION 2 FUNCTIONAL REQUIREMENTS}

Identify Required Operations:

The device shall be capable of pressing 3/16" and 1/4" spring pins out of the valve funnels in valve pits AP-02A, AP-02D, AWA, AZ, and pump pit AZ-01A.

\section{SECTION 3 PERFORMANCE REQUIREMENTS (Complete all that apply or denote as "N/A")}

\subsection{Prerequisite Conditions}

Consider attributes such as temporary conditions, high pressure/temperature requirements, and noise restrictions.

There are no temporary conditions, pressure/ temperature requirements, or noise restrictions associated with this tools use.

\subsection{Radiological Conditions}

Consider attributes such as exposure to radiation and spread of contamination.

Any waste present inside valves or piping is isolated from the valve funnel and valve funnel spring pin, the spring pin removal press will not contact waste. In the event the tool were to become contaminated, the tool is made with smooth surfaces to ease decontamination. The total duration of tool use will be minimal; therefore, radiological exposure to the components is not a factor.

\subsection{Chemical Conditions}

Consider attributes such as vapors, fumes, and aerosol.

N/A

3.4 Electrical Conditions

Consider attributes such as electrical hazards, NEC and NRTL requirements and loading.

N/A 


\section{PERFORMANCE AND FUNCTIONAL REQUIREMENTS/EVALUATION FOR SPECIAL TOOLS AND EQUIPMENT}

RPP No. 43636 Rev. 0

Page 2 of 3

\begin{tabular}{|c|c|}
\hline $\begin{array}{l}\bigotimes \text { Evaluation of Suitability for Intended Use } \\
\text { (TFC-OPS-MAINT-C-01) }\end{array}$ & $\square$ New Procurement (TFC-ENG-DESIGN-C-34) \\
\hline Work Package No.: & Purpose of Procurement: \\
\hline \multicolumn{2}{|c|}{$\begin{array}{l}\text { 3.6 Environmental Conditions } \\
\text { Consider attributes such as weather and flammable gas requirements/recommendations. } \\
\text { N/A }\end{array}$} \\
\hline \multicolumn{2}{|c|}{$\begin{array}{l}\text { 3.7 Material Requirements } \\
\text { Consider attributes such as strength of materials, welding, and coating requirements. } \\
\text { The tool is constructed of steel and this material is appropriate for the intended use. }\end{array}$} \\
\hline \multicolumn{2}{|l|}{$\begin{array}{l}\text { 3.8 Interface Hardware and Equipment } \\
\text { This tool is intended for use with a } 3 / 8 \text { " drive ratchet. }\end{array}$} \\
\hline \multicolumn{2}{|l|}{$\begin{array}{l}\text { 3.9 Lessons Learned from Past Issues and Applications } \\
\text { N/A }\end{array}$} \\
\hline \multicolumn{2}{|c|}{$\begin{array}{l}\text { 3.10 Testing Requirements } \\
\text { Consider mock-up or qualification testing requirements as applicable. } \\
\text { Shop test press on spare valve funnel before field use to verify the tool can remove a } 1 / 4 \text { " spring pin from a valve funnel. }\end{array}$} \\
\hline \multicolumn{2}{|c|}{$\begin{array}{l}\text { 3.11 Quality Assurance Requirements } \\
\text { Consider attributes such as training, inspection, and other applicable quality program requirements. } \\
\text { There are no QA requirements associated with this tool. }\end{array}$} \\
\hline SECTION $4 \quad$ ATTACHMENTS (List) & \\
\hline \multicolumn{2}{|c|}{$\begin{array}{l}\text { Tool Pictures Pages 4-11. } \\
\text { NOTE: Pictures on pages 9-11 depict the tool during construction and are for dimensional reference only. }\end{array}$} \\
\hline \multicolumn{2}{|c|}{ SECTION 5 EVALUATION RESULTS/CONCLUSION (N/A for New Procurements) } \\
\hline \multicolumn{2}{|l|}{ 5.1. Item Acceptable for Use? $\quad \bigotimes$ Yes $\square$ No } \\
\hline \multicolumn{2}{|c|}{$\begin{array}{l}\text { Valve pit and valve funnel drawings were reviewed to confirm } t \\
\text { the tool was physically inspected to ensure the tool was free fror } \\
\text { gloves, all edges were found to be ground smooth and acceptabl } \\
\text { was found to remove a } 1 / 4 \text { " spring pin easily as identified in the } \\
\text { The following documents were referenced for this evaluation: } \\
\text { ECN-726058 R0, ECN-726059 R0, ECN-726508 R0, H-14-10 }\end{array}$} \\
\hline \multicolumn{2}{|c|}{$\begin{array}{l}\text { 5.3 Limiting Conditions of Use } \\
\text { This tool shall only be used for removing } 3 / 16^{\prime \prime} \text { and } 1 / 4 " \text { spring pins from valve funnels in pits AP-02A, AP-02D, AWA, AZ, and } \\
\text { pump pit AZ-01 A. }\end{array}$} \\
\hline APPROVALS & \\
\hline
\end{tabular}




\section{PERFORMANCE AND FUNCTIONAL REQUIREMENTS/EVALUATION FOR SPECIAL TOOLS AND EQUIPMENT}

RPP No. 43636 Rev. 0

Page 3 of 3

\begin{tabular}{|l|l|}
\hline $\begin{array}{l}\text { Evaluation of Suitability for Intended Use } \\
\text { (TFC-OPS-MAINT-C-01) }\end{array}$ & $\square$ New Procurement (TFC-ENG-DESIGN-C-34) \\
\hline Work Package No.: & Purpose of Procurement: \\
\hline $\begin{array}{l}\text { Responsible Engineer } \\
\text { Josh Witherspoon }\end{array}$ \\
$\begin{array}{l}\text { Print Name, Sign } \\
\text { Engineering Manager Approval } \\
\text { John Huber }\end{array}$ \\
\hline Print Name, Sign
\end{tabular}





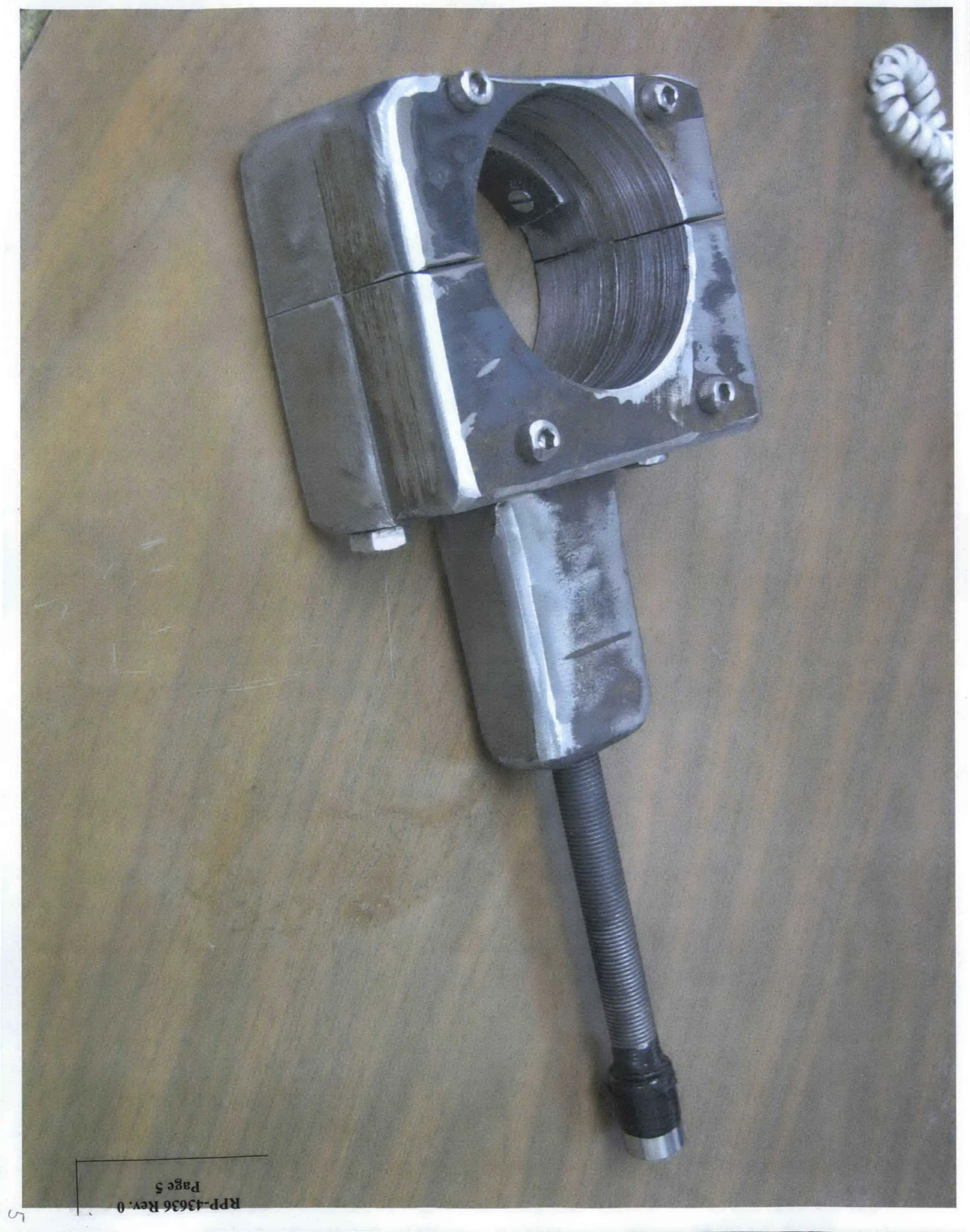




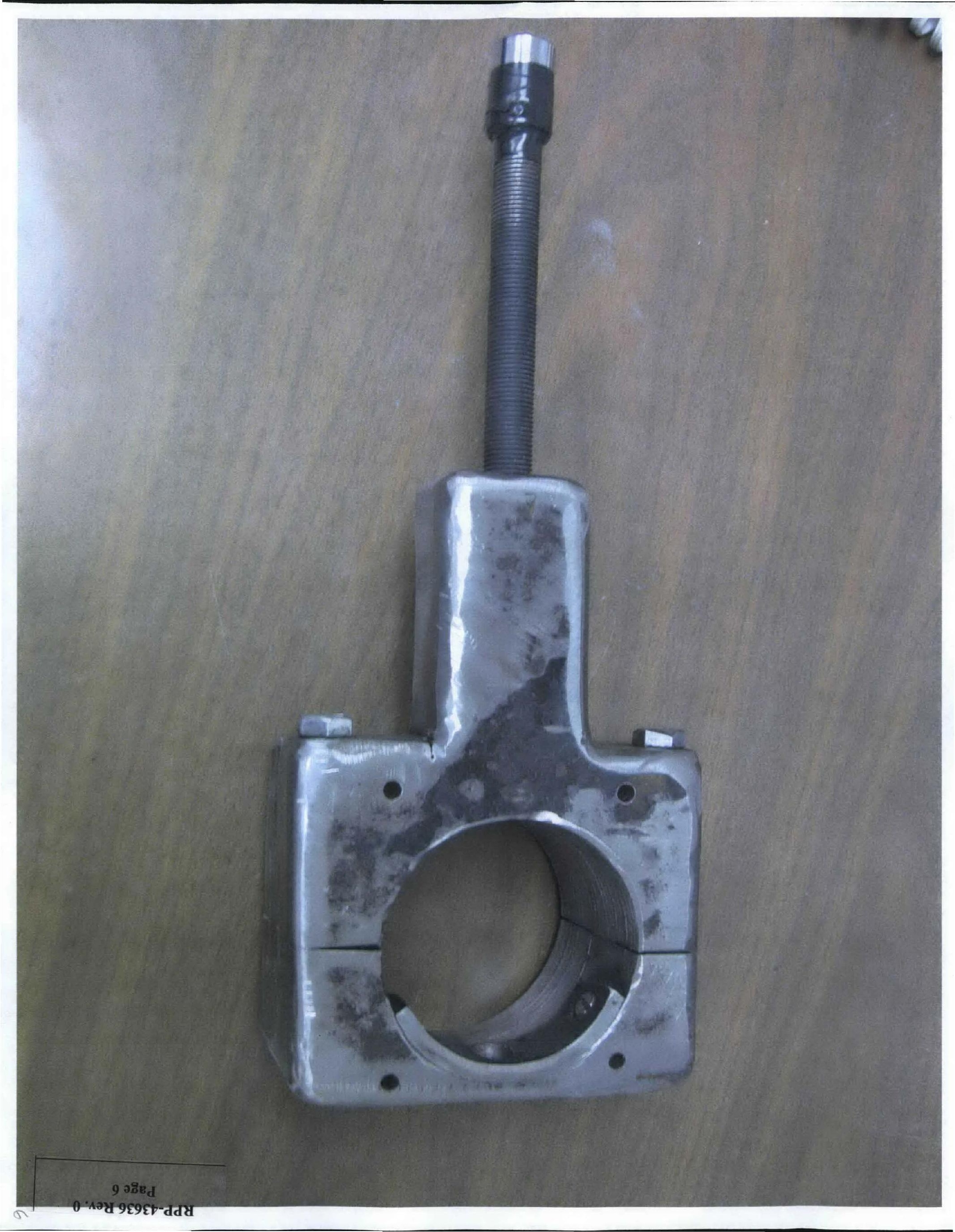




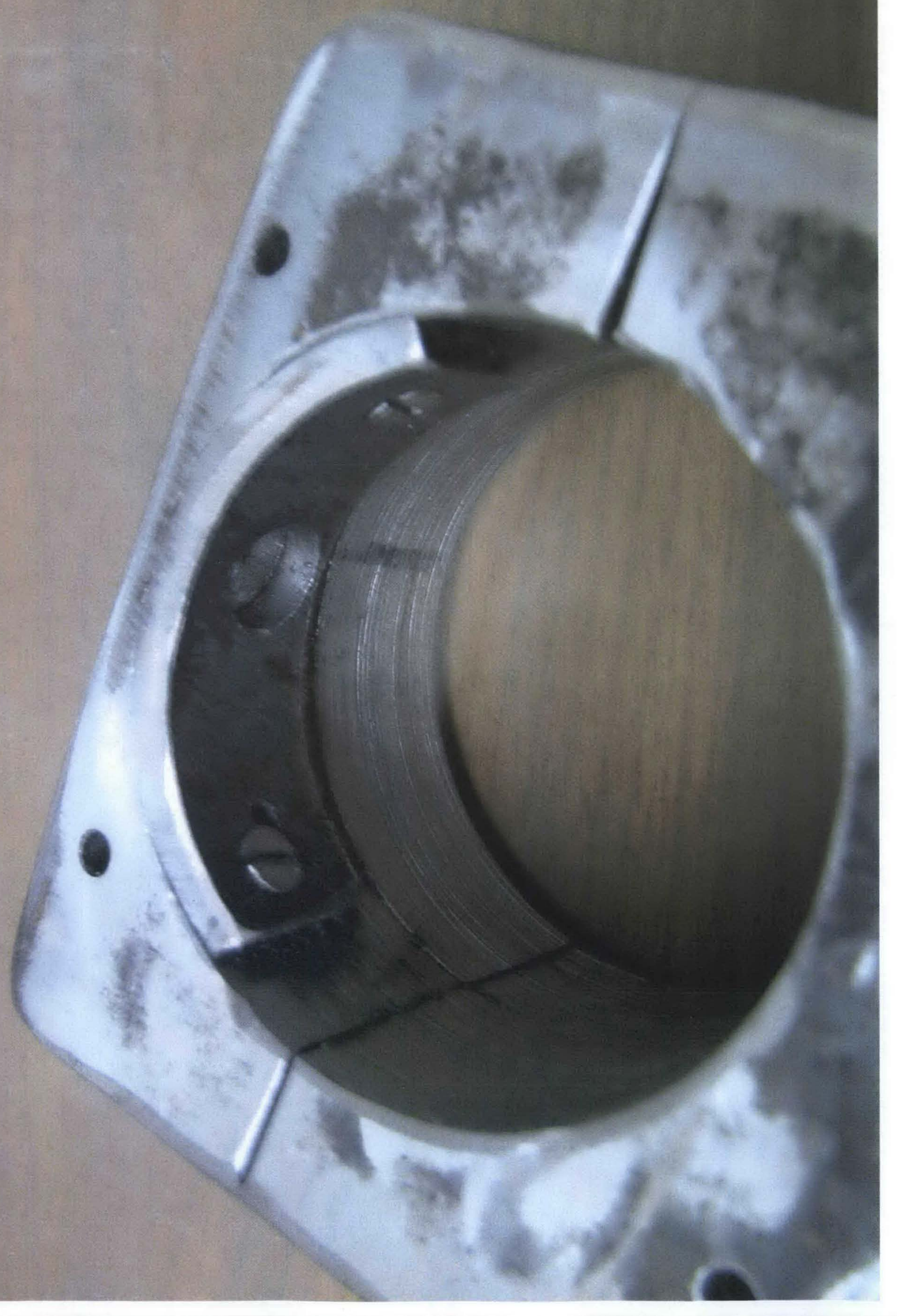



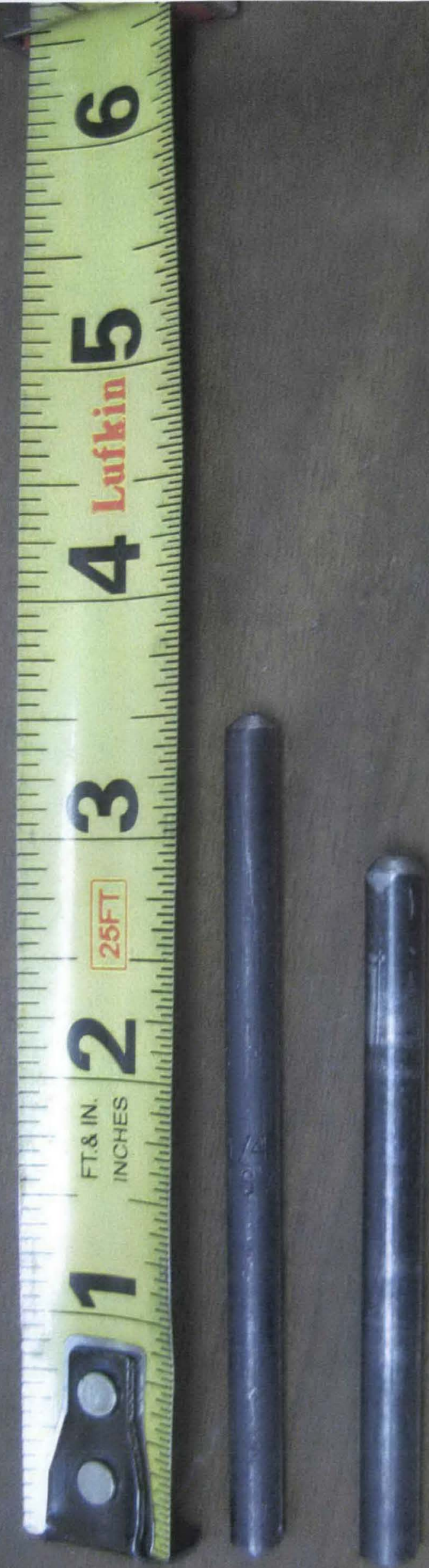


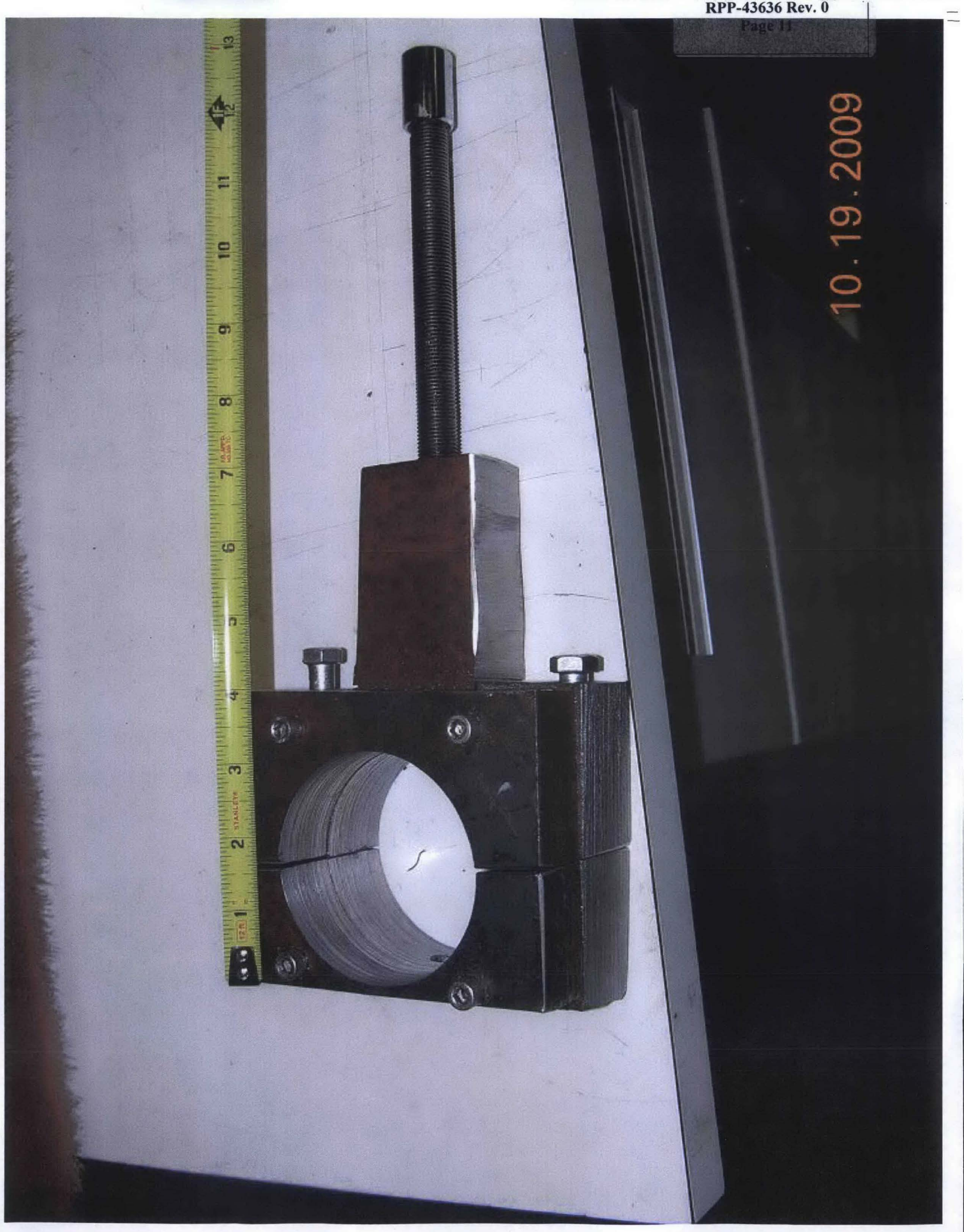

